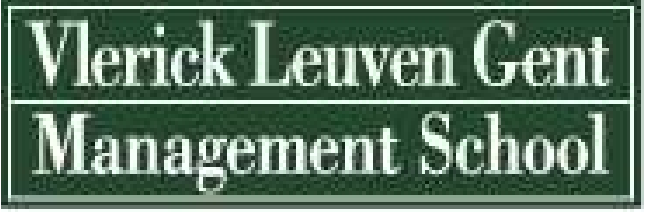

the Autovomue, Management Srhool of Chesat Daiversity ued Katholinks Unavradteit Leturme

Vlerick Leuven Gent Working Paper Series 2007/11

\title{
IDENTIFYING KEY DETERMINANTS OF EFFECTIVE BOARDS OF DIRECTORS
}

\author{
ABIGAIL LEVRAU \\ Abigail.Levrau@vlerick.be \\ LUTGART VAN DEN BERGHE \\ Lutgar.VanDenBerghe@vlerick.be
}




\title{
IDENTIFYING KEY DETERMINANTS OF EFFECTIVE BOARDS OF DIRECTORS
}

\author{
ABIGAIL LEVRAU \\ Vlerick Leuven Gent Management School \\ LUTGART VAN DEN BERGHE \\ Vlerick Leuven Gent Management School
}

This paper was presented at

- The 'Research on Friday Seminar' at the Vlerick Leuven Ghent Management School on September 29th 2006;

- $\quad$ The TEW Working Paper Forum on October 5th 2006;

- $\quad$ The Roundtable 'board effectiveness' organised by the Belgian Governance Institute on October 8th 2006;

- The 3rd Phd Workshop on Corporate Governance, The European Institute for Advanced Studies in Management (EIASM), Brussels 9-10 November 2006.

\section{Contact:}

Abigail Levrau

Vlerick Leuven Gent Management School

Tel: +32092109893

Fax: +32092109700

Email: Abigail.Levrau@vlerick.be 
We wish to thank Annick Willem and Dave Bouckenooghe for their helpful comments on earlier drafts of this manuscript. We also would like to thank the colleagues of the Belgian Governance Institute who assisted us in carrying out the many interviews. We express our gratitude to the participants of the various workshops this paper was presented at. Their feedback was of added-value for improving our own insights. Finally, this research was made possible by the support of the Belgian Governance Institute and, in particular, by its member network.

Abigail Levrau holds a degree of Applied Economic Sciences from Ghent University. She is Senior Researcher at the Vlerick Leuven Gent Management School/The Belgian Governance Institute. Her research and interests are on corporate governance, board of directors and corporate governance ratings. She is currently undertaking a $\mathrm{PhD}$ on board effectiveness.

Lutgart Van den Berghe obtained her PhD in Economics at the Ghent University on the topic of the economic value of insurance. She is extra-ordinary Professor at the Ghent University in corporate governance. She is Partner of the Vlerick Leuven Gent Management School and President of the Research Centre for Entrepreneurship, Governance and Strategy. She is Executive Director of The Belgian Directors' Institute and member of the board of directors of numerous (international) companies. 


\begin{abstract}
Mainstream research on boards of directors has been focusing on a direct relationship between board characteristics and firm performance, but up till now the results are inconclusive. Although these studies revealed interesting and useful insights, little is known about the factors that shape board effectiveness. This paper aims to reduce this gap by exploring the variety of indicators that contribute to the effectiveness of boards. The paper derives from an interview-based investigation among 104 directors of Belgian listed companies. The findings are further elaborated with quantitative data from two written questionnaires, involving directors of non-listed companies and experts in the field of corporate governance. The results point to three major issues. First, there appears to be a gap between a limited number of structural board measures consistently found in literature and the systematic occurrence of a set of behavioural criteria of board effectiveness in the perceptions of (Belgian) directors. Second, the findings suggest that the value of independence may be overemphasized at the cost of the broader issue of diversity. Third, it appears that mainstream board research ignores to a large extent two additional conditions (the information flow and the leadership style of the chairman) under which a board of directors can make an effective contribution to the strategic direction and control of a company. Our findings suggest that the ambiguity found in current research evidence can to some extent be attributed to the ignorance of a wide range of interconnected structural (such as diversity and competence) and behavioural factors (such as trust, attitude, norms and conduct) which actually shape the effectiveness of boards in performing their roles.
\end{abstract}




\section{INTRODUCTION}

Boards of directors are of interest to academics, the investment community, the business world and society at large. According to Cadbury (1999) this attention is understandable, given the fact that boards of directors serve as a bridge between the shareholders, who provide capital, and management in charge of running the company. At the heart of the corporate governance debate is the view that the board of directors is the guardian of shareholders' interest (Dalton et.al., 1998). Yet, boards are being criticized for failing to meet their governance responsibilities. Major institutional investors put pressure on (incompetent) directors and have long advocated changes in the board structure (Monks and Minow, 2001). Their call has been strengthened by many corporate governance reforms resulting from major corporate failures. The reforms put great emphasis on formal issues such as board independence, board leadership structure, board size and committees (Weil, Gotshal and Manges, 2002; Van den Berghe and De Ridder, 1999). These structural measures are assumed to be important means to enhance the power of the board, protect shareholders' interest, and hence, increase shareholder wealth (Becht et.al., 2002; Westphal, 1998).

The interest of the investment and business community in the effectiveness of corporate boards undeniable stimulated academic research. Empirical studies on boards of directors are to a large extent triggered by a common question, i.e. whether boards of directors have an impact on corporate performance. Early research on US boards showed a sad picture as it concluded that boards of directors are rather passive, dominated by management and their impact is in fact minimal (Lorsch and MacIver, 1989; Drucker, 1974; Mace, 1971). From a different angle, an extensive body of research has examined the direct impact of board attributes on firm performance. By using a firm's financial performance as a proxy, scholars have been able to empirically test a board's effectiveness in protecting shareholders' interests. Most of these studies have, however, shown inconclusive results (see the reviews by Coles et.al., 2001 and Dalton et.al., 1998). Another stream of research has investigated the influence of board attributes on the performance of board roles, suggesting an indirect causal relationship between boards of directors and company performance (see the reviews by Deutch, 2005 and Johnson et.al., 1996). 
A common feature of all these studies is the focus on a limited number of characteristics related to board composition namely insider/outsider representation, board size and CEO duality. This comes as no surprise as (i) their importance is recognized by the various theoretical perspectives on board research (Zahra and Pearce, 1989), (ii) they are common targets of those who seek to reform the corporate governance processes (Dalton et.al., 1998), and (iii) a vast majority of these studies relies on archival data gathering techniques and structural board measures provide the relative ease of data collection (Daily et.al., 2003).

Notwithstanding the fact that market parties (investors, corporate governance activists etc.) and scholars attach great importance to the same board issues, there are few definitive and striking findings to link these structural board characteristics to performance outcomes (Daily et.al., 2003). Due to the lack of clear and solid academic evidence, the appropriateness of these board measures as adequate proxies for understanding board effectiveness can be questioned. Almost two decades ago, Zahra and Pearce (1989) already argued that there is "a growing awareness of the need to understand better how boards can improve their effectiveness as instruments of corporate governance (...). The starting point for future research involves conducting extensive field work to understand better, document and operationalize board variables. More descriptive work is necessary before normative board models or theories can be advanced" (p. 327). Some scholars have tried to overcome the limitations in mainstream board research by examining the explanatory value of individual director characteristics (van der Walt and Ingley, 2003; Kesner, 1988; Vance, 1978), board working style (Gabrielsson and Winlund, 2000) and board processes (Cornforth, 2001) for the effectiveness of boards. In addition, recent qualitative research into boards of directors (Leblanc and Gillies, 2005; Roberts et.al., 2005; Huse et.al., 2005) as well as more practitioner literature (e.g. Charan, 2005; Carter and Lorsch, 2004; Sonnenfeld, 2002) have brought the importance of studying boardroom dynamics to researchers' attention. Unfortunately the conduct of extensive field work (as called upon by Zahra and Pearce (1989)) remains limited, not in the least because of difficulties of gaining access to boardrooms and directors. 
Hence, a sufficient insight into the complex web of criteria which enables (or hampers) boards of directors to be effective in conducting their roles and ultimately creating shareholder wealth is - to a large extent - still lacking (Leblanc and Gillies, 2005).

The purpose of this study is to try to fill this void as much as possible, by identifying and exploring the broad variety of criteria that may influence board effectiveness. In particular, this paper addresses the following research question: What are the key factors that contribute to the effectiveness of boards of directors?. We will investigate this question by means of a mixed methods research design, involving boards of directors of both listed and non-listed Belgian companies as well as other actors in the field. Particularly, we will explore a set of qualitative and quantitative data generated from a sample of directors, who expresses their views on the criteria of board effectiveness, based on their own (board) experience. This paper is organized in four sections. First, we outline the theoretical background. The second section contains an explanation of the research methodology, focusing on the mixed methods research design. The third section presents the results of our study. We end this paper by discussing our findings and drawing conclusions.

\section{THEORETICAL BACKGROUND}

In studying boards of directors, academic research has been concerned with mainly three board characteristics: composition, leadership structure and size. They are commonly identified by the basic theoretical perspectives on boards of directors and by consequence assumed to be important proxies for understanding board effectiveness (Zahra and Pearce, 1989).

Board composition as key determinant. The bulk of academic research on boards of directors examines the role and the proportion of inside, outside and independent directors. In essence, two theories prevail to explain the reliance either on insider or outsider-dominated boards. Agency theory, which dominates corporate governance research, is concerned with the conflicts of interest that may occur between the shareholders (principals) and the managers (agents). 
Separation of ownership and control provides the potential for managers to pursue actions which maximise their self-interest at the expense of the shareholders. The board of directors serves as an internal control mechanism in order to monitor management and to ensure shareholders' welfare (Fama and Jensen, 1983a; Jensen and Meckling, 1976). In an agency perspective, effectiveness is presumed to be a function of board independence from management. Applied to the composition of the board of directors, agency theory prescribes a preponderance of independent outside directors. The opposite perspective is grounded in stewardship theory, which perceives managers as good stewards of the company assets. Managers have a range of non-financial motives, such as the intrinsic satisfaction of successful performance, the need for achievement and recognition etc., which restrain them to misappropriate corporate resources at any price. Reallocation of control from shareholders to management leads to maximization of corporate profits and hence shareholder returns (Muth and Donaldson, 1998). Based on these assumptions, stewardship theory suggests a board of directors dominated by insiders. The empirical findings of academic research on board composition, however, do not reveal a consistent picture.

First, a rich body of literature has investigated the direct impact of board composition on a company's financial performance, but yielded mixed results. Several researchers have studied the effects of outsider-dominated boards on shareholder wealth and have found positive results. For example, Baysinger and Butler (1985) reported that firms with higher proportions of independent directors ended up with superior performance records (as measured by return on equity). Rosenstein and Wyatt (1997) found that a clearly identifiable announcement of the appointment of an outside director leads to positive effects on the firm's share price. In contrast, there is also a series of studies that do not support the postulated positive relationship. Agrawal and Knoeber (2001) and Coles et.al. (2001) reported a negative impact of greater representation of outside directors on firm performance, as measured by Tobin's Q respectively Market Value Added. In addition, Kesner's findings (1987) indicate a positive association between the proportion of inside directors and two indicators of firm financial performance, profit margin and return on assets. Still others are more reserved on the effects of board composition on corporate performance. 
Wagner et. al. (1998) conclude that both, greater insider and outsider representation can have a positive impact on performance while a meta-analyses by Dalton et.al. (1998) demonstrates that there is virtually no substantive relationship between board composition and financial performance.

Another stream of empirical research suggests that board composition is related to the board's undertaking of its roles but again the results are mixed. A fair amount of evidence supports the assumption that outside directors have been effective in monitoring management and protecting shareholder interests. Outsider-dominated boards are significantly more likely to replace an underperforming CEO (Weisbach, 1988), to prevent management from paying greenmail (Kosnik, 1987), are more involved in restructuring decisions (Johnson et. al., 1993) and are better able to distinguish between good and bad acquisitions (Byrd and Hickman, 1992). In contrast, some researchers do not support the notion that independent directors are effective guardians of shareholders' interest. For instance, no significant relationship was found between the proportion of independent directors and the adoption of a poison pill provision (Mallette and Fowler, 1992) or the number of illegal acts committed by management (Kesner et.al., 1986). Moreover, some results are rather in favour of insider-dominated boards. Research shows that the proportion of inside directors has a positive impact on R\&D spending (Baysinger et.al., 1991), innovation and diversification strategies (Hill and Snell, 1988) and is negatively associated with the incidence of golden parachute agreements (Cochran et. al., 1985).

Board leadership structure as key determinant. Board leadership structure refers to whether or not there are separate persons who serve in the roles of CEO and chairman of the board. Agency theory as well as stewardship theory are also relevant to explain the leadership structure of boards. In an agency perspective, the separation of the roles of CEO and chairman of the board is prescribed as a measure for more independent oversight. Splitting these roles dilutes the power of the CEO, avoids CEO entrenchment and reduces the potential for management to dominate the board. A separate board leadership structure provides the required check and balances and hence positively influences company performance (Zahra and Pearce, 1989). 
This view runs counter to other thinking about CEO duality. In fact, proponents of stewardship theory suggest that if the CEO also serves as the chairman, this duality provides unified firm leadership, builds trust and stimulates the motivation to perform. In this perspective, joint leadership structure facilitates better firm performance (see e.g. Finkelstein and D'Avanti, 1994; Muth and Donaldson, 1998). Empirical research on board leadership structure is rather limited and provides inconclusive results supporting, both perspectives.

Only a limited number of studies have empirically examined the effects of CEO duality on firm performance. Donaldson and Davis (1991) and Coles et al. (2001) reported a positive relationship between a combined leadership structure and shareholder returns (as measured by return on equity), respectively Economic Value Added. In contrast, Rechner and Dalton (1991) found that firms with separate board leadership structure outperformed -over a six-year time period- those relying upon a joint structure. However, a small amount of studies show no relationship between board leadership structure and firm performance (e.g. Dalton et.al., 1998, Baliga et al., 1996; Chaganti et.al., 1985). Another way of approaching this issue is by studying the joint effect of board leadership structure and board composition. In this respect a robust interaction effect is suggested between firm bankruptcy and board structure. Firms that combine the CEO and chairman roles and that have lower representation of independent directors are associated with bankruptcy (Daily and Dalton, 1994 a; Daily and Dalton, 1994 b).

Board size as key determinant. Board size is a well-studied board characteristic for two different reasons. First, the size of the board is believed to have an impact on firm performance. In particular, in accordance with agency theory, the number of directors frequently serves as an indicator of CEO domination of the board. Increasing the number of directors makes it more difficult for the CEO to dominate the board and hence enables the board to better monitor management and corporate performance (Zahra and Pearce, 1989). Besides, the importance of board size is also recognized by resource dependency theory. The central postulate of this theory is that external parties hold resources which a business organization perceives as crucial to the realization of its internal objectives (Pfeffer and Salancik, 1978). 
In order to acquire and maintain these resources, a company seeks to establish links with its environment and the board of directors is a vehicle to do so. According to this perspective, a larger board of directors is assumed to be more capable of co-opting external influences, thus obtaining valuable resources that are inevitable for corporate success (Johnson et.al., 1996). Based on these assumptions, a positive association between board size and corporate performance became conventional wisdom but the evidence of empirical research on this issue is rather inconsistent. Some early studies provide positive evidence for varying industries. According to Provan (1980), board size is one of the strongest predictors of organizational effectiveness in the human service sector. Chaganti et. al. (1985) compared the board size of failed and non-failed firms in the retailing industry and found that larger boards were associated with a higher rate of corporate survival. Pearce and Zahra (1992) found a significant positive relationship between board size and different measures of financial performance, using data from Fortune 500 industrial companies. In contrast, more recent studies reported opposite results. Yermack (1996) found a negative relationship between board size and firm market value, using a sample of large US public companies. Similar results were reported using European data. Eisenberg et. al. (1998) studied small non-listed Finnish firms and found a negative correlation between a firm's profitability and the size of its board, while the study of Conyon and Peck (1998) shows an inverse relationship between return on shareholders' equity and board size for five European countries.

Second, from a completely different angle, boards of directors are approached as decision-making groups. In this respect, board size serves as a proxy measure of directors' expertise. Larger boards are likely to have more knowledge and skill at their disposal and the ability of boards to draw on a variety of perspectives likely contributes to the quality of the decision-making (Forbes and Milliken, 1999). However, expanding the number of directors might significantly inhibit the working of a board, due to the potential group dynamic problems associated with larger groups (Jensen, 1993). Consequently, larger boards may be hampered in reaching a consensus on important decisions (Forbes and Milliken, 1999). 
A limited number of studies empirically examined the influence of board size with respect to strategic decision-making. Judge and Zeithalm (1992) found that board size was negatively associated with board involvement in strategic decisions, concluding that when boards get too large, effective debate and discussion are limited and the interaction between individual members is lower. Goodstein et.al. (1994) have explored the effects of board size on strategic changes initiated by organizations. Their results indicate that large boards have limited effectiveness in directing strategic change during periods of environmental turbulence. Also Golden and Zajac (2001) found that strategic change is significantly affected by board size. In particular, their findings indicate that an increase in board size is negatively related to strategic change for larger boards.

To summarize, the above mentioned studies show that there is no robust evidence on the relationship between structural characteristics of boards of directors and board or company performance. Although these studies revealed interesting and useful insights, the absence of clear empirical support of substantive relationships casts doubt on both the efficacy of agency theory as the dominant governance theory and the appropriateness of structural board measures as adequate proxies for understanding board effectiveness. In particular, the vast majority of empirical studies are being criticized for using a too narrow focus in assessing the effectiveness of boards in performing their governance role and its contribution to firm financial performance (Daily et al., 2003). It seems that our knowledge on the effectiveness of boards is hampered not only by the applied data gathering techniques but also by inadequate attention to the potentially large number of intervening variables between board characteristics and performance outcomes (Roberts et al., 2005; Pettigrew, 1992). 


\section{METHODS}

As indicated above, the vast majority of studies on boards of directors have relied upon quantitative data gathering techniques (Daily et.al., 2003). These techniques include mainly large scale archival data, while a subset of board studies have also used questionnaires. Although these techniques offer the advantage to analyse the data in a consistent way their access to process-oriented data is restricted (Daily et.al., 2003). Some scholars have overcome this limitation by using in-dept interviews (Roberts et al., 2005; Pettigrew and McNulty, 1998; Demb and Neubauer, 1992; Lorsch and MacIver, 1989) and direct observation techniques (Huse and Schoning, 2004; Leblanc and Gillies, 2003). Their research provides an important qualitative counter-balance to the traditional surveys on boards of directors.

In our study, we build upon the strengths of both approaches by opting for a mixed methods research design (Teddlie and Tashakkori, 2003). More specifically, we opted for a sequential exploratory design (Creswell et. al., 2003). A specific feature of this design is its two-phase approach whereby the collection and analysis of the qualitative data in an initial phase is followed by a phase of quantitative data collection and analysis. More specifically, in the first (qualitative) research phase we try to identify - by means of interviews - the full set of criteria that potentially contribute to the effectiveness of boards. The results are then used to construct a rating survey for the second (quantitative) research phase which helps us in elaborating and interpreting the qualitative findings. Furthermore, the research design implies completely different samples and data collection techniques for the two phases.

\section{Sample and data collection for the qualitative phase}

Sample. For the first qualitative research phase, we selected purposively utilizing a critical cases sampling scheme (Collins et.al., 2006). This means we intentionally limited the sample to members of the boards of directors of Belgian listed companies because we believed that they are well-placed to provide us with compelling insights into the determinants of board effectiveness. 
A sample of 147 directors of Belgian companies listed on Euronext Brussels were contacted and asked to participate in a large scale in-depth study on corporate governance in Belgium. Our sample included different directors' roles such as chairmen, independent directors, non-executive directors and CEOs. Information on the companies listed on Euronext Brussels was found on the Euronext website (www.euronext.com). Information on the boards of directors was retrieved from multiple sources such as the company's annual report, its website and the Belfirst database. Of the initial 147 directors that were contacted, a total of 104 (response rate $=71 \%$ ) agreed to participate. Table 1 presents our sample in terms of directors' roles.

\section{Insert Table 1 About Here}

Data collection. Data was collected during interviews with directors of Belgian listed companies. For the purpose of this study, a standardized open-ended question was used (Johnson and Turner, 2003). In particular, the directors were asked to sum up what they perceived as the most important ingredients of a good board of directors. In this respect, multiple answers could be given. We deliberately opted not to use the term 'effective' to avoid misunderstanding because the concept of effectiveness may yield different interpretations. By consequence, we used the word 'good'. By phrasing the question in a more neutral way, we believed that each respondent had the same understanding of the question, which diminishes bias in the answers. In addition, by using an open-ended question we were able to fully capture a broad spectrum of criteria.

\section{Sample and data collection for the quantitative phase}

Sample. For the second quantitative research phase, we selected purposively utilizing a convenience sampling scheme (Collins et.al., 2006). This means we have chosen individuals that are conveniently available and willing to participate in the study. A sample of 715 members of the Belgian Governance Institute were contacted and asked to participate in our study. 
Members include (i) directors with different roles (such as chairmen, independent, non-executive- or executive directors) representing boards of directors of listed as well as non-listed companies, and (ii) actors in the field of corporate governance (advisors, lawyers, academics etc.). Of the initial 715 directors that were contacted, a total of 166 (response rate $=23 \%$ ) respondents were engaged in the quantitative research phase. Next, in order to avoid overlap between the samples, we excluded the respondents who previously participated in the interviews. Incomplete responses were also rejected from the sample resulting in a total of 150 (response rate $=21 \%$ ). The sample can be divided in two groups of respondents. We labelled a group "directors", representing those persons who sit on boards of directors of Belgian companies and another group received the label "experts", representing actors in the field of corporate governance (see table 2).

Insert Table 2 About Here

Data collection. Two small written questionnaires were used to collect the quantitative data (see Appendix 1). The aim of the questionnaires was to reveal further gradation between various criteria which are assumed to contribute to the effectiveness of boards. For that purpose, we opted for structured closed-ended questionnaires whereby the response category took the form of rankings. The 10 questionnaire items were based on the themes (representing groupings of similar criteria) derived from the open-ended question in the qualitative phase. To avoid misunderstanding, we clearly defined what was meant by board effectiveness. In particular, board effectiveness was defined as "the degree the board is able to carry out its strategic and monitoring tasks". Furthermore, we also indicated how the rankings should be interpreted. To minimize response bias, the respondents received the questionnaires in two steps. As previously explained, the first questionnaire was submitted to the respondents who were asked to rank the items according to their importance ( 1 most important - 10 least important). After a period of time, the respondents received the second form and were asked to indicate to what extent there is room for improvement in practice (1 needs most improvement - 10 needs least improvement). 


\section{RESULTS}

\section{Qualitative analysis}

The interviews yielded a broad set of responses regarding criteria that constitute a good corporate board, as perceived by the directors. The qualitative data was analysed by coding using the ATLAS.ti software. As recommended in literature (Miles and Huberman, 1984), we developed a coding list, based upon the literature on boards of directors, insights into the corporate governance codes and complemented the list with themes that emerged during data analysis. This resulted in a total of 31 qualitative codes. The codes resemble as close as possible the directors' responses. In a next step, we grouped codes that related to similar concepts and entered these groupings as 'families' in ATLAS.ti. (see Appendix 2). The creation of families is a way to form clusters and allow easier handling of coded material (ATLAS. Ti, 2004). In addition, we used a basic form of counting during the analysis process because it allowed us to more fully describe the variety of criteria that were cited during the interviews and it helped to maintain analytical integrity (Onwuegbuzie and Teddlie, 2003). Table 3 provides a summary of the results. A detailed overview of the frequencies of each code within a family can be found in Appendix 3.

\section{Insert Table 3 About Here}

The findings presented in table 3 show that aspects related to the composition of the board are by far most frequently reported by a great number of directors. Board culture which expresses more intangible aspects of the board of directors resides on the second place, closely followed by the operations of the board. The less frequently mentioned cluster refers to the relationship of the board with management. In what follows, each of the themes will be described in more detail. 
Board composition ${ }^{1}$. In directors' perceptions, in order to be effective, the board of directors needs to have the appropriate structure. This involves several related dimensions. The most frequently cited dimension refers to diversity. The board should comprise a mix of people having different personalities, educational, occupational and functional backgrounds. As some directors pointed out: "A board of directors composed of 'clones' does not work". However, although diversity seems to be top of mind it is closely followed by the dimension of complementarity. Having different skills at the disposal of boards is a minimum requirement but they must be complementary. One director summarized this, using the following metaphor: "It is the mayonnaise that counts within a board, thanks to the different oils present". The third dimension relates to the competence of individual directors. Beyond diversity and complementarity this dimension was cited separately as one of the key criteria. Individual directors should have a minimum degree of knowledge and experience. It boils down to the capacity and quality of the people sitting on the board. Within the cluster relating to board composition, the proportion of independent directors as well as the size of the board were among the least frequently mentioned criteria.

In the cases where these criteria came across, it was noted that the board of directors should pursue a balance between executive directors, shareholders' representatives and independent directors. Moreover, the board of directors should not be too large.

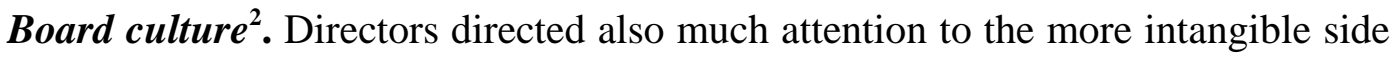
of board conduct. We labelled this theme 'board culture' referring to a set of informal unwritten rules which regulates board and directors' behaviour. The frequencies of the reported issues within this theme are very close. Most important there should be openness and transparency. Directors should have the ability to express their views and a culture of open debate should reign. This implies that matters should be treated inside the

\footnotetext{
${ }^{1}$ See Appendix 3, Table A

${ }^{2}$ See Appendix 3, Table B
} 
boardroom and not 'behind the scene'. One director formulated it as follows : "There should be no taboo.

All subjects ought to be touched upon. Directors should utter their opposition against a principle. Freedom of thought is very important." Second, involvement is also perceived as an important criterion. In contrast to a ceremonial, passive board, a good board of directors is active, interested and of added value to a company. Third, the general atmosphere or climate determines to some extent the way board members are expected to behave. This refers to a sense of humour, positive and constructive attitude, degree of professionalism etc.. Other dimensions with respect to board culture, but less often reported, are the fact that the board members needs to pursue a common vision or interest as well as to be vigilant and critical.

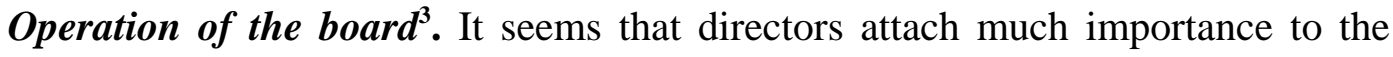
operation of the board of directors. In particular, the preparation of a board meeting was often cited as a key issue. This relates to the make-up of a board agenda and even more vital to the documents the directors receive in advance. A director commented: "A good board must be conscientiously prepared; sufficient information must be provided for each point on the agenda in such a manner that it allows directors to decide with full knowledge during board meetings".

Next, the role of the chairman was acknowledged. One director put it as follows: "The chairman is the driving force.... he is responsible for an efficient course of board meeting, he is the one who takes the plunge in case of conflict, who dare to stick its neck out... in addition, he is the hinge between shareholders, management and the board." Finally some aspects which were less frequently reported, related to the conduct of board meetings such as the length of board meetings (not too long), the quality of (management) presentations, time management etc.

\footnotetext{
${ }^{3}$ See Appendix 3, Table C
} 
Board tasks ${ }^{4}$. From a different perspective, a good board of directors was viewed in relation to the tasks it performs. Particularly, directors place emphasis on the strategic role of the board. As pointed out by the directors, the board should be involved in determining the long term strategic direction of the company. In doing so, two additional comments are of interest. First, the board must have some insight into the evolution of the business environment. One director explained "A good board of directors is able to see the present, whilst keeping an eye on the future". Second, the board must be able to translate the shareholder's strategic ambitions to management. One director expressed this as follows: "See the company through the eyes of the shareholder". In second order, the support role was mentioned. This role refers to the support the board of directors provides to management by means of challenging, advising and stimulating management. Some directors summarized this as follows: "A good board brings out the best in its management" Less attention is paid to the monitoring role of the board and the context which enables a board to fulfil it tasks. The latter refers to the degree of delegation of power within the corporate governance tripod.

Debate/decision-making ${ }^{5}$. This theme views the board of directors as a decisionmaking group. In particular, the occurrence and quality of the debate(s) are perceived as key criteria within this cluster. The board is not a rubber-stamping body. Real, in-depth discussion should take place but the deliberations should be characterised by neutrality and objectivity. Or as one director stated: "One should play the ball, not the man". To a less extent, reference was also made to the fact that directors should make a contribution in the discussions by sharing information or knowledge and the fact that the board should make decisions.

\footnotetext{
${ }^{4}$ See Appendix 3, Table D

${ }^{5}$ See Appendix 3, Table E
} 
Individual norms ${ }^{6}$. We have already touched upon the capacity and quality of the individual directors when discussing the composition of the board. In addition, more behavioural characteristics were highlighted during the interviews which we labelled as 'individual norms'. First, the personality of individual directors seems to matter. In particular, aspects such as integrity, ethics, attitude, ego etc. were mentioned. Second, it includes the commitment of individual directors referring to the personal enthusiasm, interest and availability of people sitting on a board. The least important characteristics are the independence of and preparation by individual directors.

Relationship between the board members ${ }^{7}$. Directors also paid some attention to the interpersonal relationships between the board members. Although the frequencies are quite low, some related dimensions could be singled out. First, boards need the right chemistry and foster cohesiveness. Second, informal contacts and interaction among the directors must be stimulated. Third, the board of directors must function as a team. Finally, trust and respect between the members are being valued.

Board-management relationship ${ }^{8}$. The last theme refers to dimensions regarding the relationship between the board and management, which could not be grouped within the support role of the board. More specifically, this cluster relates to the contact, symbioses with and trust in management, as well as to the quality of management. In fact, only a few directors mentioned the reliance of the board on a strong and honest management as a key criterion for its effectiveness.

\footnotetext{
${ }^{6}$ See Appendix 3, Table F

${ }^{7}$ See Appendix 3, Table G

${ }^{8}$ See Appendix 3, Table $\mathrm{H}$
} 


\section{Quantitative analysis}

The previous section has provided a descriptive analysis of the variety of criteria that potentially contribute to the effectiveness of boards. By means of two written questionnaires, the qualitative findings are further elaborated. More specifically, the questionnaires offered respondents a set of 10 determinants of board effectiveness. These determinants are not mutually exclusive, as some are closely related. The first questionnaire was aimed at getting a more profound insight into the importance rate of a select number of suggested determinants on a more quantitative base. Descriptive statistics for the full sample are given in table 4 in while Appendix 4 provides the detailed frequency table.

\section{Insert Table 4 About Here}

The results in table 4 show that a relationship of trust between the board and $\mathrm{CEO} /$ management is perceived to be the most important determinant of board effectiveness. The next-best determinants are the composition of the board in terms of complementary expertises, and a constructive critical attitude of board members. In contrast, a chairman who seeks consensus as well as board members who get along very well appear to be of little importance for the effectiveness of boards.

In order to reveal a more fine-grained view on the importance rate, we have divided our sample into two groups. A first group represents the "directors" while a second group represents the "experts". In fact, we are interested to see if directors' perceptions on the determinants of board effectiveness differ from those of experts in the field of corporate governance. Table 4 presents the descriptive statistics for both groups. 
The descriptive results in table 5 indicate some differences between the perceptions of directors and experts with respect to the importance rate, as only 3 of the 10 suggested determinants rank the same (trust between the board and $\mathrm{CEO} /$ management, sufficient and timely information, consensus-seeking by the chairman). The views of directors and experts diverge, in particular, regarding the importance of board members' constructive critical attitude. The deviation in the ranking score is the greatest for this determinant (ranked $2^{\text {nd }}$ for directors while $5^{\text {th }}$ for experts). Although our data set can be claimed for statistical ordinal testing, it does not fulfil the requirements for the computation of a Pearson Chi-Square correlation coefficient mainly because of low frequencies per cell (with respect to the responses of the expert group).

The second questionnaire was used to explore how the suggested determinants occur in practice. In particular, it yielded quantitative data reflecting respondents' perceptions on the (same) listed items in terms of their need for improvement. Descriptives of the corrigible rate for the full sample are given in table 6 while Appendix 4 provides the detailed frequency table.

\section{Insert Table 6 About Here}

The results in table 6 indicate that the preparation of board members, a sufficient and timely information flow and the active participation in discussions by all directors are most capable of improvement. In contrast, consensus-driven deliberations, guided by the chairman and a good relationship among the board members are perceived to be least capable of improvement.

Similar to the analysis of the importance scores, it is possible to reveal a more fine-grained view on the corrigible rate, by dividing our sample into two groups. A first group represents the "directors" while a second group represents the "experts". In fact, we are interested to see if directors and experts view the need for improvement of the suggested determinants differently. Table 6 presents the descriptive statistics for both groups. 
The descriptive results in table 7 indicate great similarities between the perceptions of directors and experts with respect to the corrigible rate, as 7 of the 10 suggested determinants rank the same. The views of directors and experts seem only to diverge regarding the need for improvement of tolerating divergent opinions, trust between the board of directors and CEO/management and consensus-seeking by the chairman. Although our data set can be claimed for statistical ordinal testing, it does not fulfil the requirements for the computation of a Pearson Chi-Square correlation coefficient mainly because of low frequencies per cell.

Finally, matching the importance rate of the determinants of board effectiveness to their corrigible rate reveals the gaps that exist, and at the same time points out the criteria that limit the board's potential to fulfil its strategic and monitoring role. Figure 2 illustrates the link between the importance of determinants of board effectiveness and their need for improvement.

Insert Figure 2 About Here

Quadrant 1 denotes determinants of board effectiveness representing 'type 1' which we term flashing lights. In particular, this quadrant groups criteria which are perceived to be very important for the effectiveness of boards and at the same time require most improvement in practice. Put differently, the findings suggest that too little complementarity in the expertises present, absence of a critical attitude in discussions, insufficient diversity regarding directors' roles or unprepared board members may hamper the board in carrying out its duties.

Quadrant 2 denotes determinants of board effectiveness representing 'type 2' which we term challengers. In particular, this quadrant groups criteria which are perceived to be very important for the effectiveness of boards while at the same time require only little or no improvement in practice. It appears that only one criterion fits into this quadrant, that is the relationship between the board and management. 
Although this relationship seems not to pose many problems in practice the challenge to maintain a balance of trust between the board of directors and $\mathrm{CEO} /$ management inheres in the governance of every company. A relationship of trust can easily be broken at any point in time and therefore requires continuous effort of both governing bodies.

Quadrant 3 denotes determinants of board effectiveness representing 'type 3' which we term subordinates. In particular, this quadrant groups criteria which are perceived to be of less importance for the effectiveness of boards and at the same time require only little or no improvement in practice. These criteria are perceived to be inferior compared to the other groups. Our findings suggest that when divergent opinions are tolerated in board meetings, the chairman seeks consensus or directors are getting along, this does not significantly add value to the ability of a board in performing its roles (compared to type 1 and type 2 ).

Quadrant 4 denotes determinants of board effectiveness representing 'type 4' which we term seducers. In particular, this quadrant groups criteria which are perceived to be of less importance for the effectiveness of boards while at the same time being most corrigible in practice. The findings suggest that getting appropriate information beforehand and watching over an actively participation of all directors in discussions are two criteria which should be addressed as practice shows major shortcomings on these issues. Still, the danger exists that these criteria might mislead attention and effort from the more critical aspects of board effectiveness (type 1 and type 2). 


\section{DISCUSSION}

Three major points emerge from this study. First, there appears to be a gap between a limited number of structural board measures consistently found in literature and the broad set of criteria that are emphasized in directors' perceptions, in particular the systematic occurrence of a set of behavioural criteria of board effectiveness. Mainstream board research has been heavily influenced by a research tradition from financial economics and theories treating the board of directors as a "black box". Although boards of directors are frequently studied in academic research, scholars have traditionally focused on a limited number of characteristics such as board size, board composition and board leadership. These structural measures are commonly viewed as appropriate and adequate proxies for understanding board effectiveness, while the working processes of boards or individual directors' behaviour are rarely investigated. A such, the various research streams suggest that if the structure of a board is appropriate, the board should be able to fulfil its duties, and ultimately enhance corporate performance. However, little convincing evidence exists that these structural measures, which are presumed to contribute to the effectiveness of boards as guardians of shareholders' welfare, have had considerable impact on the financial performance of companies. Moreover, the data collected in this study reveals a huge discrepancy between the criteria found in academic literature and the perceptions of the directors themselves. Our qualitative findings have revealed an enlarged set of board attributes and suggest a more prominent role for intangible or 'soft' factors as determinants for board effectiveness. More then half of the directors interviewed put great emphasis on the informal rules which regulate board and directors' behaviour ('board culture'), while more then fourth stressed the importance of debate as a criteria for a good corporate board. The quantitative results retrieved from the questionnaires elaborate this qualitative evidence. They highlight the importance of trust between the board and $\mathrm{CEO} /$ management as well as the behaviour of board members with respect to their preparation, participation and critical attitude in boardroom deliberations. Our findings suggest that board of directors and board effectiveness in particular, should also be understood through attributes reflecting the board's inner workings and not solely through attributes of board structure and composition. Besides, our findings are to a large extent consistent and supported with evidence from other qualitative board studies. 
The latter have also drawn attention to the importance of the human element in board effectiveness. A climate of trust and candour, a culture of open dissent, collective wisdom, collective strength and behavioural expectations are some of the elements put forward to increase board performance (Leblanc and Gillies, 2005; Charan, 2005; Carter and Lorsch, 2004; Sonnenfeld, 2002).

A second major point is that the value of independence may be overemphasized at the cost of the broader issue of diversity. Stimulated by the dominance of the agency perspective in corporate governance, board effectiveness has commonly been approached as the ability of boards to act independently from management. Board independence has been the cornerstone of the corporate governance debate, although considerable divergent views exist both on the right proportion of independent directors and their definition (Van den Berghe and Baelden, 2005; Daily et.al. 1999;). It is assumed that independent directors add real value to a company and arguments in favour of their appointment are well-documented (Felton et.al., 1995). Corporate governance reforms tend to support the plea for board independence by advocating that a critical mass of independent directors is essential for a board to be able to provide critical oversight. Although our findings also highlight the importance of having a sufficient mix of directors' roles in terms of executives, non-executives and independent directors, they suggest that competencies, diversity and complementarity are more pivotal attributes for board effectiveness. These criteria were among the most cited in the interviews and the dimension of complementarity systematically received high rankings in the questionnaires. Still, the issue of diversity is to a large extent neglected in board research in spite of the fact that a small number of studies already presented interesting findings. For example, Golden and Zajac (2001) found that specific types of directors' expertise or experience are influential in shaping the orientation of a board toward strategic change. In addition, corporate governance and shareholder activists are increasingly becoming convinced by the added value of diversity in terms of improved decision-making. 
Boards have commonly been viewed as homogenous groups of executives and non-executives directors who are cut from the same cloth and it is argued that this uniformity undermines the quality and variety of boardroom debate (Grady, 1999). Consequently, institutional investors have begun to pressure companies to diversify their board composition with respect to gender, race and type of expertise. TIAA-CREF, for example, puts major focus on qualified directors who reflect a diversity of background and experience (TIAA-CREF, 2006).

A third major issue is that mainstream board research ignores to a large extent two additional conditions under which a board of directors can make an effective contribution to the strategic direction and control of a company. First, our findings suggest that board members should become sufficiently knowledgeable about the particular company context. During the interviews, the aspect of preparation of board meetings in terms of agenda and information provided to directors was frequently cited. The quantitative evidence endorsed this finding as both timely and sufficient information and the preparation of board members received high rankings scores as determinants of board effectiveness. The need to adequately inform board members is also recognized by other scholars involved in qualitative board research. It is generally accepted that non-executive and independent directors face a disadvantageous position with regard to information gathering. Non-executive and independent directors, who spend only a limited amount of time with the company, can never know as much as the executive directors. They depend to a large extent on the goodwill of the management to obtain relevant and timely information. Consequently, it is assumed that in order to be able to perform its duties, directors need to be well informed at all times (Charan, 1998). The corporate scandals are only some examples of boards that knew too little too late. In addition, it is noted that a dysfunctional information flow may hinder the performance of boards. Some boards receive bundles of documents, but only a small part may be useful in gaining an understanding of the real issues the board should be addressing (Monk and Minow, 1996). Also Lorsch and MacIver (1989), in studying American boards, reported that information is often provided in such a complex way that directors have a problem in interpreting and using it. 
A study by Lawler et. al. (2001) points out that those boards whose directors have a greater amount of relevant information appear to perform their roles more effectively than boards that are less well informed. Second, our findings suggest a pivotal role of the chairman in the effectiveness of boards. In particular, the qualitative data suggest that the leadership style of the chairman plays a major role in the way the board is able to carry out its duties. However, the academic governance literature traditionally looks at the issue of board leadership in quite narrow terms by focusing the discussion on the relationship of the chairman and the CEO. Especially, the question whether the two functions should be separated or not has received considerable attention and continues to be subject to much debate. Still, the effects of a separation of roles have not been consistently substantiated by empirical evidence. In addition, only a handful of studies exist, which have examined the role of the chairman and its impact on the effectiveness of boards. For example, Roberts (2002) documents how the unskilful management of board relationships and processes can easily disable a board in its decision-making and performance. Based on the nature of chairman/chief executive relationships, he distinguishes three dysfunctional board dynamics - a competitive, personal and captured board - with negative consequences for board effectiveness. Also the earlier study of Pettigrew and McNulty (1995) already pointed to the key role a chairman plays in shaping board dynamics and transforming a 'minimalist' board to a 'maximalist' board, having a strong impact on the direction of a company. However, an unexpected finding in our study relates to the role of the chairman in board decision-making. The results from the written questionnaire suggest that in order for the board to be effective it is not important that a chairman seeks consensus. As such, this finding does not support the study of Hill (1995) who found that maintaining boardroom consensus was a fundamental value among all directors he surveyed and which was definitely the norm within the executive grouping. A possible explanation relates to the interpretation of the notion of consensus. Additional comments by directors revealed that consensus might be interpreted as 'unanimity' and consequently bias responses. They noted that a good board of directors reach a decision that is supported by all board members even though there exists personal disagreement. 


\section{CONCLUSION}

The purpose of this study was to get a better understanding of the various criteria that contribute to the effectiveness of boards. In order to do so, we conducted an in-depth review of the literature and complemented the insights with the findings of an extensive field study. The analysis is primarily intended to be exploratory and descriptive while using both qualitative and quantitative data. The first research phase is based on a large number of interviews and yielded a broad spectrum of criteria that constitutes a good board of directors, as perceived by the directors. By coding the criteria and clustering them into separate groups we were able to grasp the variety of criteria. Moreover, the technique of counting (the frequency a criterion was mentioned) provided a first indication of which criteria matter more. The importance rate of a limited number of potential determinants of board effectiveness was further examined in the quantitative research phase by means of a written questionnaire. In addition, a second questionnaire was used to further elaborate the findings by exploring how the suggested determinants occur in practice. The overall results raised three major issues which were then discussed more in-depth. What becomes clear by our research is that many aspects of board effectiveness are invisible to 'outsiders' and as a result poorly understood. Most researchers have remained at a considerable distance from actual board practice, partly because of difficulties of gaining access. By consequence, they focus their attention on a small number of structural board characteristics leading to inconclusive findings. Our findings suggest that this ambiguity in current research evidence can to some extent be attributed to the ignorance of a wide range of interconnected structural (such as diversity and competence) and more behavioural factors (such as trust, attitude, norms and conduct) which actually shape the effectiveness of boards in performing their roles.

Various avenues of further research can be identified. First, our study is limited to a description of a broad set of criteria which are presumed to have an impact on board effectiveness. At this stage, we are unable to pronounce upon the way the different criteria interact. More research is required to examine the interrelationship between the criteria in order to develop a new theoretical model for board effectiveness or to adjust and refine existing board models. It is also advocated to test the identified relationships on a large scale to validate the new proxies that can be used to measure board effectiveness. 
Second, no reference was made to contingencies which may influence the effectiveness of boards and hence directors' perceptions. In particular, it can be stated that specific board attributes that are beneficial for one company may turn out to be detrimental to an other. By consequence, it is suggested to get a better insight into the context and to identify the conditions under which a board can or will be effective in performing its roles. Third, the findings of the study also point to the need of a multidisciplinary approach in board research. The latter should not be restricted to the use of different research techniques but should also incorporate relevant literature, such as literature on group effectiveness, TMT decision-making, organizational demography etc.

This study makes at least three contributions to the corporate governance literature. A first contribution stems from the study of boards of directors in a non-US context using an alternative research methodology. In spite of the intense research interest in corporate governance systems and mechanisms around the world (Schleifer and Vishny, 1997), most (empirical) studies on boards of directors have been carried out by using samples of large US corporations and are inspired by quantitative US research traditions (Huse, 2005). In contrast, qualitative studies on boards of directors as well as research of boards in European contexts are still very scarce. Our research contributes to reduce the observed gap in existing board literature by studying boards of directors in a Belgian context with a qualitative-oriented research approach (mixed methods design). Second, our study also emphasizes the potential importance of board diversity as additional (structural) measure of board composition. Rather than approaching the board of directors exclusively in terms of insiders versus outsiders, researchers should consider to integrate measures of diversity that reflect the differences in backgrounds, experiences and skills (Kosnik, 1990). Third, this study also stresses the need to examine the inner workings of boards. A common feature of mainstream board research is the treatment of the board of directors as a "black box" (Daily et.al., 2003). The inconclusive findings of studying direct relationships between board characteristics and performance outcomes, however, raise doubt on the explanatory power of these input-output models. One way to make progress in board research is to develop and adopt indirect research models which take into account more behavioural aspects of board conduct. 


\section{REFERENCES}

Agrawal, A., C.R. Knoeber. 1996 Firm Performance and Mechanisms to Control Agency Problems between Managers and Shareholders. Journal of Financial and Quantitative Analysis. 31(3) 377-397.

Baliga, B.R., R.C. Moyer, R.S. Rao. 1996. CEO duality and firm performance: what's the fuss? Strategic Management Journal. 17 41-43.

Baysinger, B.D., H.N. Butler. 1985. Corporate governance and the board of directors: performance effects of changes in board composition. Journal of Law, Economics and Organization. 1(Fall) 101-124.

Baysinger, B.D., R.D. Kosnik, T.A. Turk. 1991b. Effects of board and ownership structure on corporate R\&D strategy. Academy of Management Journal. 34 205-214

Becht, M., P. Bolton, A. Röel. 2002. Corporate Governance and control. Working paper 9371, National Bureau of Economic Research.

Byrd, J.W., K.A. Hickman. 1992. Do outside directors monitor managers? Evidence from tender offer bids. Journal of Financial Economics. 32 195-221.

Cadbury, A. 1999. What are the trends in corporate governance? How will they impact your company. Long Range Planning. 32(1) 12-19.

Carter, C.B., J.W. Lorsch .2004. Back to the Drawing Board. Designing Corporate Boards for a Complex World. Harvard Business School Press. Boston Massachusetts

Charan, R. 1998. Boards at Work. How Corporate Boards create Competitive Advantage. Jossey-Bass Inc., A Wiley Company. California

Charan, R. 2005. Boards that deliver. Advancing Corporate Governance - From Compliance to Competitive Advantage. Jossey-Bass Inc., A Wiley Company. California 
Chaganti R., V. Mahajan, S. Sharma. 1985. Corporate board size. composition and corporate failures in retailing industry. Journal of Management Studies. 22 400-416.

Cochran, R.L., R.A. Wood, R.B. Jones. 1985. The composition of boards of directors and the incidence of golden parachutes. Academy of Management Journal. 28(3) 664-671.

Coles, J.W., V.B. McWilliams, N. Sen. 2001. An examination of the relationship of governance mechanisms to performance. Journal of Management. 27(1) 23-50.

Collins, K.M.T., A.J. Onwuegbuzie, Q.G.Jiao. 2006. Prevalence of mixed methods sampling designs in social science research. Paper presented at the annual meeting of the American Educational Research Association. San Francisco. CA. April 1-7. 2006.

Conger, J.A., E.E. Lawler III and D.L. Finegold. 2001. Corporate Boards. New Strategies for adding Value at the Top. Jossey-Bass Inc., A Wiley Company. California

Conyon, M.J., S.I. Peck. 1998. Board size and corporate performance: evidence from European countries. The European Journal of Finance. 4(3) 291-304.

Cornforth, C. 2001. What makes boards effective? An examination of the relationships between board inputs, structures, processes and effectiveness of non-profit organisations. Corporate Governance: An International Review. 9(3) 217-227

Creswell, J.W., V.L. Plano Clark, M.L. Gutmann M.L.,W.E. Hanson. 2003. “Advanced mixed methods research designs". In C. Teddlie and A. Tashakkori (Eds), Handbook of Mixed Methods in Social and Behavioural Research. Thousand Oaks, Sage Publications.

Daily, C.M., J.L. Johnson, D.R. Dalton. 1999. On the measurement of board composition: poor consistency and a serious mismatch of theory and operationalization. Decision Sciences. 30(1) 83-106.

Daily, C.M., D.R. Dalton, A.A.Cannella jr. 2003. Corporate governance: decades of dialogue and data. Academy of Management Review. 28(3) 371-382. 
Daily, C.M., D.R. Dalton. 1994 a. Bankruptcy and corporate governance: The impact of board composition and structure. Academy of Management Journal. 37(6) 1603-1617.

Daily, C.M., D.R. Dalton. 1994 b. Corporate governance and the bankrupt firm: an empirical assessment. Strategic Management Journal. 15 643-654.

Dalton, D.R., C.M. Daily, A.E. Ellstrand, J.L. Johnson. 1998. Meta-analytic reviews of board composition, leadership structure and financial performance. Strategic Management Journal. 19(3) 269-290.

Demb, A., F-F. Neubauer. 1992. The Corporate Board. Confronting the Paradoxes. Oxford University Press. Inc.

Deutsch, Y. 2005. The impact of board composition on firms' critical decisions: a metaanalytic review. Journal of Management. 31(3) 424-444.

Donaldson, L., J.H. Davis. 1991. Stewardship theory or agency theory : CEO governance and shareholder returns Australian. Journal of Management. 16 49-64.

Drucker, P.F. 1974. Management : tasks, responsibilities, practices. Harper and Row. New York

Eisenberg, T., S. Sundgren, M.T. Wells. 1998. Larger board size and decreasing firm value in small firms. Journal of Financial Economics. 48 35-54.

Fama, E.F., M.C. Jensen. 1983. Separation of ownership and control. Journal of Law and Economics. 26(2) 327-349.

Felton R.F., A. Hudnut, V. Witt. 1995. Building a stronger board. The McKinsey Quarterly. 2 163-175

Finkelstein, S., R.A. D’Aveni. 1994. CEO duality as a double-edged sword : How boards of directors balance entrenchment avoidance and unity of command. Academy of Management Journal. 37 1079-1108 . 
Forbes, D.P., F. Milliken. 1999. Cognition and corporate governance: understanding board of directors as strategic decision-making groups. Academy of Management Review. 24(3) 489-505.

Gabriellson, J., H. Winlund. 2000. Boards of directors in small and medium-sized industrial firms: examining the effects of the board's working style on board task performance. Entrepreneurship and Regional Development. 12 311-330

Golden, B.R., E.J. Zajac. 2001. When will boards influence strategy? Inclination x power = strategic change. Strategic Management Journal. 22(12) 1087-1111.

Goodstein, J., K. Gautam, W. Boeker. 1994. The effects of board size and diversity on strategic change. Strategic Management Journal. 15(3) 241-250.

Grady D. 1999. No more board games! The McKinsey Quarterly 3 17-25

Hill, C.W.L., S.A. Snell. 1988. External control. corporate strategy and firm performance in research-intensive industries. Strategic management Journal. 9 577-590.

Hill, S. 1995. The social organization of boards of directors. The Britisch Journal of Sociology. 46(2) 245-278

Huse, M., M. Schoning. 2004. Group dynamics and decision processes in boards of directors: observations from flies on the wall. Paper prepared for the $20^{\text {th }}$ EGOS Colloquium. July 1-3. Ljubljana, Slovenia.

Jensen, M.C., W.H. Meckling.1976. Theory of the firm: managerial behaviour, agency costs and ownership structure. Journal of Financial Economics. 3(4) 305-360.

Jensen, M.C. 1993. The modern industrial revolution. Exit and failure of internal control systems. Journal of Finance. 48(3) 831-880.

Johnson R. B. and L.A. Turner. 2003. Data collection strategies in mixed methods research. In A. Tashakkori and C. Teddlie (Eds.) Handbook of mixed methods in social and behavioral research (pp. 297-319). Thousand Oaks, Sage Publications. 
Johnson, J.L., C.M. Daily, A.E. Ellstrand. 1996. Boards of directors: a review and research agenda. Journal of Management. 22(3) 409-438.

Johnson, R.A., R.E. Hoskisson, M.A. Hitt. 1993. Board of director involvement in restructuring: the effects of board versus managerial controls and characteristics. Strategic Management Journal. 14(4) 33-50.

Judge, W.Q., C.P. Zeithaml. 1992. Institutional and strategic choice perspectives on board involvement in the strategic decision process. Academy of Management Journal. 35(4) 766-794.

Kesner, I.F. 1987. Directors' stock ownership and organizational performance : an investigation of Fortune 500 companies. Journal of Management. 13(3) 499-508.

Kesner, I.F., B.Victor, B. Lamont. 1986. Board composition and the commission of illegal acts : an investigation of Fortune 500 companies. Academy of Management Journal. 29(4) 789-799.

Kesner, I.F. 1988. Directors' characteristics and committee membership : an investigation of type, occupation, tenure and gender. Academy of Management Journal. 31 66-84.

Kosnik, R.D. 1990. Effects of board demography and directors' incentives on corporate greenmail decisions. Academemy of Management Journal 33 129-151.

Lawler, E.E.III. 2002. Corporate boards : keys to effectiveness. Organizational Dynamics 30(4) 310-324

Leblanc, R., J. Gillies. 2003. "Improving Board Decision-Making: An Inside View", Paper presented at the 6th International Conference on Corporate Governance and Direction, Henley Management College, Oct 6-8. 
Leblanc, R., J. Gillies. 2005. Inside the Board Room. How Boards Really work and the coming Revolution in Corporate Governance. Jossey-Bass Inc., A Wiley Company. California

Lorsch, J.W., E. MacIver E. 1989. Pawns or Potentates. The Reality of America's Corporate Boards. Harvard Business School Press. Boston. Massachusetts.

Mace, M.L.G. 1971. Directors: myth and reality. Division of Research Graduate School of Business Administration Harvard University. Boston

Malette, P., K.L. Fowler. 1992. Effects of board composition and stock ownership on the adoption of poison pills. Academy of Management Journal. 35(5) 1010-1035.

Miles, M., A. Huberman. 1984. Drawing valid meaning from qualitative data : toward a shared craft. Educational Researcher.13 20-30.

Monks, R.A.G., N. Minow. 2001. Corporate Governance. $2^{\text {nd }}$ Edition, Oxford: Blackwell Publishers Inc.

Muth, M.M., L. Donaldson. 1998. Stewardship theory and board structure : a contingency approach. Corporate Governance - An International Review. 6(1) 5-27.

Onwuegbuzie, A.J., C. Teddlie. 2003. A Framework for Analyzing Data in Mixed Methods Research. In C. Teddlie and A. Tashakkori (eds), Handbook of Mixed Methods in Social and Behavioural Research. Thousand Oaks: Sage Publications.

Pearce, J.A.II, S.A. Zahra S.A. 1992. Board composition from a strategic contingency perspective. Journal of Management Studies. 29 (4) 411-438.

Pettigrew, A. 1972. On studying Managerial Elites. Strategic Management Journal. 13(8). 163-182.

Pettigrew, A., T. McNulty. 1995. Power and influence in and around the boardroom. Human Relations. 48(8) 845-873 
Pfeffer, J., G.R. Salancik. 1978. The external control of organisations: a resource dependence perspective. Harper and Row, New York.

Provan, K.G. 1980. Board power and organizational effectiveness among human service agencies. Academy of Management Journal. 23 221-236.

Rechner, P.K., D.R. Dalton. 1991. CEO duality and organizational performance: a longitudinal analysis. Strategic Management Journal. 12(2) 155-160.

Roberts, J.T. 2002. Building the complementary board. The work of the Plc Chairman. Long Range Planning 35 493-520

Roberts, J.T., P. Mc Nulty, P. Stiles. 2005. Beyond agency conceptions of the work of the non-executive directors: creating accountability in the boardroom. Britisch Journal of Management. 16 Special Issue S5-S6

Rosenstein, S., J.G. Wyatt. 1990. Outside directors, board independence and shareholder wealth. Journal of Financial Economics. 26(2) 175-191.

Shleifer, A., R.Vishny. 1997. A survey of corporate governance. Journal of Finance. 52(2): 737-783.

Sonnenfeld, J.A. 2002. What makes great boards great. Harvard Business Review. 8 106113

Teddlie C. and A. Tashakkori. 2003. "Handbook of Mixed Methods in Social and Behavioural Research. Thousand Oaks: Sage Publications.

TIAA-CREF (Teachers Insurance and Annuity Association-College Retirement Equities Fund). 2006. Policy Statement of Corporate Governance. New York http://www.tiaacref.org/pubs/html/governance_policy/index.html

Vance, S.C. 1978. Corporate Governance: assessing corporate performance by boardroom attributes. Journal of Business Research. 6 203-230 
Van den Berghe, L., T. Baelden. 2005. The complex relation between director independence and board effectiveness. Corporate Governance: International Journal of Business in Society. 5 (5) : 58 -84.

Van den Berghe, L., A. Levrau, S. Carchon, C. Van der Elst. 2002. Corporate Governance in a Globalising World: Convergence or Divergence? A European Perspective. Kluwer Academic Publishers. Boston.

Van den Berghe L., L. De Ridder.1999. International Standardisation of Good Corporate Governance. Kluwer Academic Publishers.

Van der Walt, N., C. Ingley. 2003. Board dynamics and the influence of professional background, gender and ethnic diversity of directors. Corporate Governance : An International Review. 11 218-234

Wagner, J.A.., J.L. Stimpert, E.I. Fubara. 1998. Board composition and organisational performance: two studies of insider/outsider effects. Journal of Management Studies. 35(5) 655-677.

Westphal, J.D. 1998. Board games : how CEOs adapt to increases in structural board independence from management. Administrative Science Quarterly. 43(3) 511-537.

Weil Gotshal \& Manges LLP. 2002. Comparative Study of Corporatie Governance Codes Relevant to the European Union and Its Member States, FINAL REPORT \& ANNEXES I-III on behalf of the EUROPEAN COMMISSION Internal Market Directorate General, In consultation with EASD - European Associatoin of securities dealers \& ECGNEuropean Corporatie Governance network . 
Weisbach, M.S. 1988. Outside directors and CEO turnover. Journal of Financial Economics. 20 431-460.

Yermack, D. 1996. Higher market valuation of companies with a small board of directors. Journal of Financial Economics. 40(2) 185-211.

Zahra, S.A., J.A. Pearce II. 1989. Boards of directors and corporate financial performance: a review and integrative model. Journal of Management. 15(2) 291-334. 


\section{APPENDIX 1}

\section{EXAMPLE OF THE FIRST QUESTIONNAIRE (in Dutch)}

\section{Board effectiveness}

Hieronder vindt $\mathrm{u}$ een lijst met tien stellingen. De stellingen omvatten diverse aspecten die de doeltreffendheid van de raad van bestuur kunnen beïnvloeden. "Board effectiveness" wordt daarbij gedefinieerd als "de mate waarin de raad van bestuur zijn strategische en controlerende rol vervult". Deze stellingen zijn gebaseerd op een uitgebreide literatuurstudie en eerder uitgevoerd kwalitatief onderzoek. De bedoeling is dat $u$ volgende stellingen naar belangrijkheid rangschikt in dalende orde (1 MEEST belangrijk - 10 MINST belangrijk).

\begin{tabular}{|l|l|}
\hline OPDAT DE RVB ZIJN STRATEGISCHE EN CONTROLERENDE ROL ZOU KUNNEN VERVULLEN IS & RANGORDE \\
HET BELANGRIJK DAT ...... & \\
\hline $\begin{array}{l}\text { Er in de RvB zowel leden van het management, onafhankelijke bestuurders als } \\
\text { vertegenwoordigers van de aandeelhouders zetelen }\end{array}$ & 10 \\
\hline De bestuurders goed voorbereid zijn & 5 \\
\hline Alle bestuurders actief deelnemen aan de discussies & 4 \\
\hline De bestuurders constructief kritisch ingesteld zijn & 3 \\
\hline Er vertrouwen is tussen de raad van bestuur en CEO/management & 9 \\
\hline De voorzitter consensus nastreeft & 1 \\
\hline De informatie voldoende en tijdig is & 2 \\
\hline Afwijkende visies getolereerd worden & 8 \\
\hline Er complementariteit is op vlak van achtergrond, expertise en ervaring & 7 \\
\hline De bestuurders goed met elkaar opschieten & 6 \\
\hline
\end{tabular}

Uw e-mail : 


\section{EXAMPLE OF THE SECOND QUESTIONNAIRE (in Dutch)}

\section{Board effectiveness : deel 2}

Hieronder vindt $\mathrm{u}$ een lijst met tien stellingen. De stellingen omvatten diverse aspecten die de doeltreffendheid van de raad van bestuur kunnen beïnvloeden. "Board effectiveness" wordt daarbij gedefinieerd als "de mate waarin de raad van bestuur zijn strategische en controlerende rol vervult". Deze stellingen zijn gebaseerd op een uitgebreide literatuurstudie en eerder uitgevoerd kwalitatief onderzoek. De bedoeling is dat $u$, vanuit uw bestuurservaring, aangeeft welke aspecten in de praktijk het meest voor verbetering vatbaar zijn. Gelieve deze in dalende volgorde te rangschikken (1 MEEST voor verbetering vatbaar - 10 MINST voor verbetering vatbaar).

\begin{tabular}{|l|l|}
\hline & RANGORDE \\
\hline De informatie is voldoende en tijdig & 5 \\
\hline De bestuurders zijn constructief kritisch ingesteld & 6 \\
\hline De bestuurders zijn goed voorbereid & 1 \\
\hline Alle bestuurders nemen actief deel aan de discussies & 4 \\
\hline Complementariteit op vlak van achtergrond, expertise en ervaring & 2 \\
\hline Er is vertrouwen tussen de raad van bestuur en CEO/management & 8 \\
\hline De voorzitter streeft consensus na & 9 \\
\hline Afwijkende visies worden getolereerd & 7 \\
\hline Mix management, onafhankelijke bestuurders en vertegenwoordigers van de & 3 \\
aandeelhouders & \\
\hline De bestuurders kunnen goed met elkaar opschieten & 10 \\
\hline
\end{tabular}

Uw e-mail : 


\section{APPENDIX 2}

\section{FAMILY}

DEBATE/DECISION-MAKING

\section{BOARD CULTURE}

active involvement

openness

critical

common values or goa

atmosphere-climate

\section{INTERPRETATION/DEFINITION}

refers to the fact that discussions take place; no rubber-stamping

refers to the characteristics of the discussions such as neutral, objective, in-depth, open, critical, emotionless, based on facts, to the point ....

relates to the participation in the discussions and the assumption that members contribute during the disscusions (e.g. sharing of knowledge, information, ideas etc)

refers to the fact that decisions are taken

refers to the fact that a board is interested and involved in the company; it takes initiatives, learns and contributes in contrast to a formal, passive board

refers to an open culture, the possibility or ability to express an opinion, transparency ....

refers to a critical attitude/behaviour

refers to the fact that group members have a common denominator

relates to other unwritten rules or standards such as humour, a positive and constructive mind, professionalism, passion for excellence .... 
commitment

preparation

personality

independence refers to the fact that individual members are interested, involved and available (sufficient time)

refers to the fact that individual members are prepared (e.g. read the documents)

relates to characteristics of the personality of individual members such as humility, ego, attitude, sense of responsibility, integrity, ethical

refers to the courage of individual members to speak up and to show an independent mind

\section{RELATIONSHIPS AMONG THE}

BOARD MEMBERS

cohesiveness

respect

team

trust

contact refers to the chemistry and the fact that board members cohere

refers to the fact that the board members respect each other

refers to the fact that board members operate as a team/group refers to the trust among the board members

refers to the interaction, dynamic and the informal contacts between the board members 


\section{BOARD TASKS}

context

control

strategy refers to the conditions which are necessary to fullfil the tasks (e.g. delegation, position within the CG-tripod)

relates to the monitoring tasks a board is expected to fullfil (financial, legal, internal governance etc.)

relates to the involvement of the board in the strategic process

relates to the interaction of the board with its management (challenging, stimulating, sounding board, advising etc.)

\section{BOARD-MANAGEMENT}

RELATIONSHIP

relationship with

management

relates to the contact, symbiose with and trust in management, as well as to the quality of management

\section{BOARD COMPOSITION}

refers to the fact that experienced, high-quality and competent members are sitting on the board

complementarity

diversity

refers to the fact that members differ in background, views, experience, nationality etc.

refers to the fact that various categories of directors are represented (executives, non-executives and independent directors)

mix

relates to the limitation on the number of directors 
meeting

chairmanship relates to the characteristics of the board meeting such as frequencie, timing, presentations, minutes

refers to the fact that the board meeting should be well-prepared in terms of agenda and information provided to the members

relates to the quality and role of the chairman of the board 
APPENDIX 3

Table A : detailed overview of elements of cluster 1

\begin{tabular}{lccc}
\hline Board composition & $\begin{array}{c}\text { Number of } \\
\text { respondents who } \\
\text { mentioned this } \\
\text { element }\end{array}$ & $\begin{array}{c}\text { \% of respondents } \\
(\mathbf{N}=104)\end{array}$ & $\begin{array}{c}\text { Frequency this element is } \\
\text { reported }\end{array}$ \\
\hline Diversity & 30 & $28,85 \%$ & $\mathrm{~N}=31$ \\
Complementarity & 27 & $25,96 \%$ & $\mathrm{~N}=27$ \\
Competence & 25 & $24,04 \%$ & $\mathrm{~N}=25$ \\
Mix (executive/non-executive) & 10 & $9,62 \%$ & $\mathrm{~N}=11$ \\
Size & 7 & $6,73 \%$ & $\mathrm{~N}=7$ \\
\hline Total & 99 & $95,19 \%$ & $\mathrm{~N}=101$ \\
\hline
\end{tabular}

Table B : detailed overview of elements of cluster 2

\begin{tabular}{lccc}
\hline Board culture & $\begin{array}{c}\text { Number of } \\
\text { respondents who } \\
\text { mentioned this } \\
\text { element }\end{array}$ & $\begin{array}{c}\text { \% of respondents } \\
(\mathbf{N = 1 0 4 )}\end{array}$ & $\begin{array}{c}\text { Frequency this element is } \\
\text { reported }\end{array}$ \\
\hline Openness & 17 & $16,35 \%$ & $\mathrm{~N}=17$ \\
Active involvement & 15 & $14,42 \%$ & $\mathrm{~N}=15$ \\
Atmosphere-climate & 11 & $10,58 \%$ & $\mathrm{~N}=12$ \\
Common values or goal & 6 & $5,77 \%$ & $\mathrm{~N}=7$ \\
Critical & 4 & $3,85 \%$ & $\mathrm{~N}=4$ \\
\hline Total & 53 & $50,96 \%$ & $\mathrm{~N}=55$ \\
\hline
\end{tabular}

Table C : detailed overview of elements of cluster 3

\begin{tabular}{lccc}
\hline Operations of the board & $\begin{array}{c}\text { Number of } \\
\text { respondents who } \\
\text { mentioned this } \\
\text { element }\end{array}$ & $\begin{array}{c}\text { \% of respondents } \\
(\mathbf{N = 1 0 4 )}\end{array}$ & $\begin{array}{c}\text { Frequency this element is } \\
\text { reported }\end{array}$ \\
\hline Preparation & 23 & $22,12 \%$ & $\mathrm{~N}=27$ \\
Chairmanship & 18 & $17,31 \%$ & $\mathrm{~N}=18$ \\
Meeting & 8 & $7,69 \%$ & $\mathrm{~N}=9$ \\
\hline Total & 49 & $47,12 \%$ & $\mathrm{~N}=54$ \\
\hline
\end{tabular}


Table D : detailed overview of elements of cluster 4

\begin{tabular}{lccc}
\hline Board tasks & $\begin{array}{c}\text { Number of } \\
\text { respondents who } \\
\text { mentioned this } \\
\text { element }\end{array}$ & $\begin{array}{c}\text { \% of respondents } \\
(\mathbf{N}=\mathbf{1 0 4})\end{array}$ & $\begin{array}{c}\text { Frequency this element is } \\
\text { reported }\end{array}$ \\
\hline Strategy & 15 & $14,42 \%$ & $\mathrm{~N}=17$ \\
Support & 9 & $8,65 \%$ & $\mathrm{~N}=9$ \\
Context & 5 & $4,81 \%$ & $\mathrm{~N}=6$ \\
Control & 5 & $4,81 \%$ & $\mathrm{~N}=5$ \\
\hline Total & 34 & $32,69 \%$ & $\mathrm{~N}=37$ \\
\hline
\end{tabular}

Table E : detailed overview of elements of cluster 5

\begin{tabular}{lccc}
\hline Debate/decision-making & $\begin{array}{c}\text { Number of } \\
\text { respondents who } \\
\text { mentioned this } \\
\text { element }\end{array}$ & $\begin{array}{c}\text { \% of respondents } \\
(\mathbf{N = 1 0 4 )}\end{array}$ & $\begin{array}{c}\text { Frequency this element is } \\
\text { reported }\end{array}$ \\
\hline Quality & 10 & $9,62 \%$ & $\mathrm{~N}=11$ \\
Occurrence & 10 & $9,62 \%$ & $\mathrm{~N}=10$ \\
Contribution & 5 & $4,81 \%$ & $\mathrm{~N}=5$ \\
Decision & 3 & $2,88 \%$ & $\mathrm{~N}=3$ \\
\hline Total & 28 & $26,92 \%$ & $\mathrm{~N}=29$ \\
\hline
\end{tabular}

Table F : detailed overview of elements of cluster 6

\begin{tabular}{lccc}
\hline Individual norms & $\begin{array}{c}\text { Number of } \\
\text { respondents who } \\
\text { mentioned this } \\
\text { element }\end{array}$ & $\begin{array}{c}\text { \% of respondents } \\
(\mathbf{N}=\mathbf{1 0 4})\end{array}$ & $\begin{array}{c}\text { Frequency this element is } \\
\text { reported }\end{array}$ \\
\hline Personality & 9 & $8,65 \%$ & $\mathrm{~N}=10$ \\
Commitment & 8 & $7,69 \%$ & $\mathrm{~N}=10$ \\
Independence & 6 & $5,77 \%$ & $\mathrm{~N}=6$ \\
Preparation & 2 & $1,92 \%$ & $\mathrm{~N}=2$ \\
\hline Total & 25 & $24,04 \%$ & $\mathrm{~N}=28$ \\
\hline
\end{tabular}


Table G : detailed overview of elements of cluster 7

\begin{tabular}{lccc}
\hline $\begin{array}{l}\text { Relationship among the } \\
\text { board members }\end{array}$ & $\begin{array}{c}\text { Number of } \\
\text { respondents } \\
\text { who mentioned } \\
\text { this element }\end{array}$ & $\begin{array}{c}\text { \% of respondents } \\
(\boldsymbol{N}=\mathbf{1 0 4})\end{array}$ & $\begin{array}{c}\text { Frequency this element is } \\
\text { reported }\end{array}$ \\
\hline Cohesiveness & 8 & $7,69 \%$ & $\mathrm{~N}=8$ \\
Contact & 5 & $4,81 \%$ & $\mathrm{~N}=5$ \\
Team & 5 & $4,81 \%$ & $\mathrm{~N}=5$ \\
Respect & 3 & $2,88 \%$ & $\mathrm{~N}=3$ \\
Trust & 2 & $1,92 \%$ & $\mathrm{~N}=2$ \\
\hline Total & 23 & $22,12 \%$ & $\mathrm{~N}=23$ \\
\hline
\end{tabular}

Table $\mathbf{H}$ : detailed overview of elements of cluster 8

\begin{tabular}{lccc}
\hline $\begin{array}{l}\text { Board-management } \\
\text { relationship }\end{array}$ & $\begin{array}{c}\text { Number of } \\
\text { respondents who } \\
\text { mentioned this } \\
\text { element }\end{array}$ & $\begin{array}{l}\text { \% of respondents } \\
(N=104)\end{array}$ & $\begin{array}{l}\text { Frequency this elemet is } \\
\text { reported }\end{array}$ \\
\hline Relationship with management & 6 & $5,77 \%$ & $\mathrm{~N}=7$ \\
\hline Total & 6 & $5,77 \%$ & $\mathrm{~N}=7$ \\
\hline
\end{tabular}




\section{APPENDIX 4}

Table I: frequency table of importance ranking scores for the full sample $(\mathrm{N}=150)$

\begin{tabular}{|c|c|c|c|c|c|c|c|c|c|c|}
\hline Determinants of board effectiveness & $1 *$ & 2 & 3 & 4 & 5 & 6 & 7 & 8 & 9 & $10^{* * *}$ \\
\hline $\begin{array}{l}\text { The board of directors includes a mix of } \\
\text { executives, independent directors and non- } \\
\text { executives representing the shareholders }\end{array}$ & $24,0 \%$ & $11,3 \%$ & $5,3 \%$ & $6,0 \%$ & $8,7 \%$ & $7,3 \%$ & $8,7 \%$ & $8,7 \%$ & $8,7 \%$ & $11,3 \%$ \\
\hline The board members are well-prepared & $8,7 \%$ & $12,7 \%$ & $18,7 \%$ & $18,7 \%$ & $16,7 \%$ & $10,7 \%$ & $7,3 \%$ & $5,3 \%$ & $1,3 \%$ & $0,0 \%$ \\
\hline $\begin{array}{l}\text { Board members show a constructive critical } \\
\text { attitude }\end{array}$ & $10,7 \%$ & $18,7 \%$ & $16,0 \%$ & $18,0 \%$ & $8,0 \%$ & $16,0 \%$ & $6,7 \%$ & $3,3 \%$ & $1,3 \%$ & $1,3 \%$ \\
\hline $\begin{array}{l}\text { Trust between the board of directors and } \\
\text { CEO/management }\end{array}$ & $25,3 \%$ & $12,0 \%$ & $13,3 \%$ & $8,0 \%$ & $8,0 \%$ & $9,3 \%$ & $10,7 \%$ & $7,3 \%$ & $4,7 \%$ & $1,3 \%$ \\
\hline The chairman seeks consensus & $2,0 \%$ & $2,0 \%$ & $3,3 \%$ & $2,0 \%$ & $7,3 \%$ & $7,3 \%$ & $16,0 \%$ & $16,7 \%$ & $31,3 \%$ & $12,0 \%$ \\
\hline The information is sufficient and on time & $5,3 \%$ & $14,0 \%$ & $13,3 \%$ & $12,0 \%$ & $16,0 \%$ & $13,3 \%$ & $9,3 \%$ & $8,7 \%$ & $4,7 \%$ & $3,3 \%$ \\
\hline Divergent opinions are tolerated & $3,3 \%$ & $2,7 \%$ & $8,7 \%$ & $12,0 \%$ & $12,0 \%$ & $15,3 \%$ & $14,0 \%$ & $19,3 \%$ & $11,3 \%$ & $1,3 \%$ \\
\hline $\begin{array}{l}\text { Complementarity with respect to background, } \\
\text { expertise and experience }\end{array}$ & $15,3 \%$ & $20,0 \%$ & $10,0 \%$ & $10,7 \%$ & $10,7 \%$ & $7,3 \%$ & $10,7 \%$ & $8,0 \%$ & $5,3 \%$ & $2,0 \%$ \\
\hline Board members get along very well & $1,3 \%$ & $2,0 \%$ & $0,7 \%$ & $1,3 \%$ & $0,7 \%$ & $1,3 \%$ & $4,0 \%$ & $9,3 \%$ & $18,7 \%$ & $60,7 \%$ \\
\hline
\end{tabular}

* score 1 denotes 'item is most important'

**score 10 denotes 'item is least important' 
Table J: frequency table of corrigible ranking scores for the full sample $(\mathrm{N}=75)$

\begin{tabular}{|c|c|c|c|c|c|c|c|c|c|c|}
\hline Determinants of board effectiveness & $1 *$ & 2 & 3 & 4 & 5 & 6 & 7 & 8 & 9 & $10 * *$ \\
\hline $\begin{array}{l}\text { The board of directors includes a mix of } \\
\text { executives, independent directors and non- } \\
\text { executives representing the shareholders }\end{array}$ & $13,3 \%$ & $6,7 \%$ & $8,0 \%$ & $6,7 \%$ & $4,0 \%$ & $6,7 \%$ & $9,3 \%$ & $10,7 \%$ & $18,7 \%$ & $16,0 \%$ \\
\hline The board members are well-prepared & $20,0 \%$ & $25,3 \%$ & $18,7 \%$ & $12,0 \%$ & $12,0 \%$ & $6,7 \%$ & $1,3 \%$ & $0,0 \%$ & $2,7 \%$ & $1,3 \%$ \\
\hline $\begin{array}{l}\text { All directors actively participate in the } \\
\text { discussions }\end{array}$ & $8,0 \%$ & $14,7 \%$ & $20,0 \%$ & $20,0 \%$ & $4,0 \%$ & $10,7 \%$ & $9,3 \%$ & $6,7 \%$ & $4,0 \%$ & $2,7 \%$ \\
\hline $\begin{array}{l}\text { Board members show a constructive critical } \\
\text { attitude }\end{array}$ & $4,0 \%$ & $9,3 \%$ & $14,7 \%$ & $21,3 \%$ & $13,3 \%$ & $13,3 \%$ & $8,0 \%$ & $8,0 \%$ & $2,7 \%$ & $5,3 \%$ \\
\hline $\begin{array}{l}\text { Trust between the board of directors and } \\
\text { CEO/management }\end{array}$ & $0,0 \%$ & $5,3 \%$ & $5,3 \%$ & $4,0 \%$ & $10,7 \%$ & $8,0 \%$ & $21,3 \%$ & $16,0 \%$ & $20,0 \%$ & $9,3 \%$ \\
\hline The chairman seeks consensus & $0,0 \%$ & $2,7 \%$ & $5,3 \%$ & $1,3 \%$ & $16,0 \%$ & $13,3 \%$ & $12,0 \%$ & $14,7 \%$ & $16,0 \%$ & $18,7 \%$ \\
\hline The information is sufficient and on time & $29,3 \%$ & $17,3 \%$ & $10,7 \%$ & $5,3 \%$ & $13,3 \%$ & $4,0 \%$ & $5,3 \%$ & $5,3 \%$ & $5,3 \%$ & $4,0 \%$ \\
\hline Divergent opinions are tolerated & $6,7 \%$ & $4,0 \%$ & $4,0 \%$ & $8,0 \%$ & $12,0 \%$ & $18,7 \%$ & $20,0 \%$ & $14,7 \%$ & $10,7 \%$ & $1,3 \%$ \\
\hline $\begin{array}{l}\text { Complementarity with respect to background, } \\
\text { expertise and experience }\end{array}$ & $17,3 \%$ & $13,3 \%$ & $10,7 \%$ & $16,0 \%$ & $12,0 \%$ & $12,0 \%$ & $2,7 \%$ & $8,0 \%$ & $4,0 \%$ & $4,0 \%$ \\
\hline Board members get along very well & $1,3 \%$ & $1,3 \%$ & $2,7 \%$ & $5,3 \%$ & $2,7 \%$ & $6,7 \%$ & $10,7 \%$ & $16,0 \%$ & $16,0 \%$ & $37,3 \%$ \\
\hline
\end{tabular}

*score 1 denotes 'item needs most improvement'

** score 10 denotes 'item needs least improvement' 


\section{TABLE 1}

\section{(qualitative) sample per directors' role}

\begin{tabular}{|c|c|}
\hline Directors' role & Number \\
\hline Chairmen & 41 \\
\hline Chairman $=\mathrm{CEO}$ & 18 \\
\hline Chairman $=$ independent director & 11 \\
\hline Chairman $=$ non-executive director & 12 \\
\hline Executive directors & 35 \\
\hline CEOs & 30 \\
\hline Other executives & 5 \\
\hline Non-executive directors & 25 \\
\hline Independent directors & 21 \\
\hline Non-executive shareholders' representatives & 4 \\
\hline Secretary-generals & 3 \\
\hline Total & 104 \\
\hline
\end{tabular}


TABLE 1

(quantitative) sample per group of respondents

\begin{tabular}{l|lr}
\hline Respondent & Number \\
\hline Directors & 119 & \\
\multicolumn{2}{|l|}{ Representing listed companies } & 12 \\
$\quad$ Representing non-listed companies & 107 \\
Experts & 31 & \\
\hline Total & 150 \\
\hline
\end{tabular}




\section{TABLE 2}

\section{Ingredients of a good corporate board - directors' perspectives}

\begin{tabular}{l|cc|c}
\hline Families & $\begin{array}{l}\text { Number of } \\
\text { respondents } \\
\text { who referred } \\
\text { to this theme }\end{array}$ & $\begin{array}{l}\text { \% of } \\
\text { respondents } \\
\text { (N=104) }\end{array}$ & $\begin{array}{l}\text { Frequency this } \\
\text { theme was } \\
\text { reported }\end{array}$ \\
\hline Theme 1: board composition & 99 & $95 \%$ & $\mathrm{~N}=101$ \\
Theme 2: board culture & 53 & $51 \%$ & $\mathrm{~N}=55$ \\
Theme 3: operation of the board & 49 & $47 \%$ & $\mathrm{~N}=54$ \\
Theme 4: board tasks & 34 & $33 \%$ & $\mathrm{~N}=37$ \\
Theme 5: debate/decision-making & 28 & $27 \%$ & $\mathrm{~N}=29$ \\
Theme 6: individual norms & 25 & $24 \%$ & $\mathrm{~N}=28$ \\
Theme 7: relationships between the board members & 23 & $22 \%$ & $\mathrm{~N}=23$ \\
Theme 8: board-management relationship & 6 & $6 \%$ & $\mathrm{~N}=7$ \\
\hline
\end{tabular}




\section{TABLE 3}

Descriptive statistics of importance rate for the full sample $(N=150)$

\begin{tabular}{|c|c|c|c|}
\hline \multirow[t]{2}{*}{ Determinants of board effectiveness } & \multicolumn{2}{|c|}{ in top $3 *$} & \multirow[t]{2}{*}{ Rank } \\
\hline & \# & $\%$ & \\
\hline Trust between the board of directors and CEO/management & 76 & 50,6 & 1 \\
\hline Complementarity with respect to background, expertise and experience & 68 & 45,3 & 2 \\
\hline Board members show a constructive critical attitude & 68 & 45,3 & 2 \\
\hline $\begin{array}{c}\text { The board of directors includes a mix of executives, independent } \\
\text { directors and non-executives representing the shareholders }\end{array}$ & 61 & 40,6 & 4 \\
\hline The board members are well-prepared & 60 & 40,0 & 5 \\
\hline The information is sufficient and on time & 49 & 32,6 & 6 \\
\hline All directors actively participate in the discussions & 29 & 19,3 & 7 \\
\hline Divergent opinions are tolerated & 22 & 14,6 & 8 \\
\hline The chairman seeks consensus & 11 & 7,3 & 9 \\
\hline Board members get along very well & 6 & 4,0 & 10 \\
\hline
\end{tabular}

$*$ denotes the frequency the item received a ranking score $\leq 3$ 


\section{TABLE 4}

\section{Descriptive statistics of importance rate for sub-samples}

\begin{tabular}{|c|c|c|c|c|c|c|}
\hline \multirow[b]{3}{*}{ Determinants of board effectiveness } & \multicolumn{3}{|c|}{ DIRECTORS $(N=119)$} & \multicolumn{3}{|c|}{$\operatorname{EXPERTS}(N=31)$} \\
\hline & \multicolumn{2}{|c|}{ in top $3 *$} & \multirow[b]{2}{*}{ Rank } & \multicolumn{2}{|c|}{ in top $3^{*}$} & \multirow[b]{2}{*}{ Rank } \\
\hline & $\#$ & $\%$ & & $\#$ & $\%$ & \\
\hline $\begin{array}{l}\text { Trust between the board of directors and } \\
\mathrm{CEO} / \text { management }\end{array}$ & 59 & 49,6 & 1 & 17 & 54,8 & 1 \\
\hline Board members show a constructive critical attitude & 58 & 48,7 & 2 & 13 & 32,3 & 5 \\
\hline $\begin{array}{l}\text { Complementarity with respect to background, } \\
\text { expertise and experience }\end{array}$ & 51 & 42,9 & 3 & 17 & 54,8 & 1 \\
\hline $\begin{array}{l}\text { The board of directors includes a mix of executives, } \\
\text { independent directors and non-executives } \\
\text { representing the shareholders }\end{array}$ & 47 & 39,5 & 4 & 14 & 45,2 & 3 \\
\hline The board members are well-prepared & 46 & 38,7 & 5 & 14 & 45,2 & 3 \\
\hline The information is sufficient and on time & 37 & 31,1 & 6 & 12 & 38,7 & 6 \\
\hline All directors actively participate in the discussions & 27 & 22,7 & 7 & 2 & 6,5 & 8 \\
\hline Divergent opinions are tolerated & 17 & 14,3 & 8 & 5 & 16,1 & 7 \\
\hline The chairman seeks consensus & 10 & 8,4 & 9 & 1 & 3,2 & 9 \\
\hline Board members get along very well & 5 & 4,2 & 10 & 1 & 3,2 & 9 \\
\hline
\end{tabular}

* denotes the frequency the item received a ranking score $\leq 3$ 
Table 5: descriptive statistics of corrigible rate for the full sample $(\mathrm{N}=75)$

\begin{tabular}{|c|c|c|c|}
\hline \multirow{2}{*}{ Determinants of board effectiveness } & \multicolumn{2}{|c|}{ in top $3^{*}$} & \multirow[t]{2}{*}{ rank } \\
\hline & \# & & \\
\hline The board members are well-prepared & 48 & 64,0 & 1 \\
\hline The information is sufficient and on time & 43 & 57,3 & 2 \\
\hline All directors actively participate in the discussions & 32 & 42,7 & 3 \\
\hline Complementarity with respect to background, expertise and experience & 31 & 41,3 & 4 \\
\hline Board members show a constructive critical attitude & 21 & 28,0 & 5 \\
\hline $\begin{array}{l}\text { The board of directors includes a mix of executives, independent directors } \\
\text { and non-executives representing the shareholders }\end{array}$ & 21 & 28,0 & 6 \\
\hline Divergent opinions are tolerated & 11 & 14,7 & 7 \\
\hline Trust between the board of directors and CEO/management & 8 & 10,7 & 8 \\
\hline The chairman seeks consensus & 6 & 8,0 & 9 \\
\hline Board members get along very well & 4 & 5,3 & 10 \\
\hline
\end{tabular}

$*$ denotes the frequency the item received a ranking score $\leq 3$ 
TABLE 6

Descriptive statistics of corrigible rate for sub-samples

\begin{tabular}{|c|c|c|c|c|c|c|}
\hline \multirow[b]{3}{*}{ Determinants of board effectiveness } & \multicolumn{3}{|c|}{ DIRECTORS $(N=56)$} & \multicolumn{3}{|c|}{$\operatorname{EXPERTS}(N=19)$} \\
\hline & \multicolumn{2}{|c|}{ in top $3 *$} & \multirow[b]{2}{*}{ rank } & \multicolumn{2}{|c|}{ in top $3 *$} & \multirow[b]{2}{*}{ rank } \\
\hline & \# & $\%$ & & $\#$ & $\%$ & \\
\hline The board members are well-prepared & 37 & 66,1 & 1 & 11 & 57,9 & 1 \\
\hline The information is sufficient and on time & 33 & 58,9 & 2 & 10 & 52,6 & 2 \\
\hline All directors actively participate in the discussions & 25 & 44,6 & 3 & 7 & 36,8 & 3 \\
\hline $\begin{array}{l}\text { Complementarity with respect to background, } \\
\text { expertise and experience }\end{array}$ & 25 & 44,6 & 4 & 6 & 31,6 & 4 \\
\hline Board members show a constructive critical attitude & 16 & 28,6 & 5 & 5 & 26,3 & 5 \\
\hline $\begin{array}{l}\text { The board of directors includes a mix of executives, } \\
\text { independent directors and non-executives } \\
\text { representing the shareholders }\end{array}$ & 16 & 28,6 & 5 & 5 & 26,3 & 5 \\
\hline Divergent opinions are tolerated & 6 & 10,7 & 7 & 5 & 26,3 & 5 \\
\hline $\begin{array}{l}\text { Trust between the board of directors and } \\
\text { CEO/management }\end{array}$ & 6 & 10,7 & 8 & 2 & 10,5 & 9 \\
\hline The chairman seeks consensus & 2 & 3,6 & 9 & 4 & 21,1 & 8 \\
\hline Board members get along very well & 2 & 3,6 & 9 & 2 & 10,5 & 9 \\
\hline
\end{tabular}




\section{FIGURE 2}

\section{Linking importance and corrigible scores of determinants of board effectiveness ${ }^{9}$}

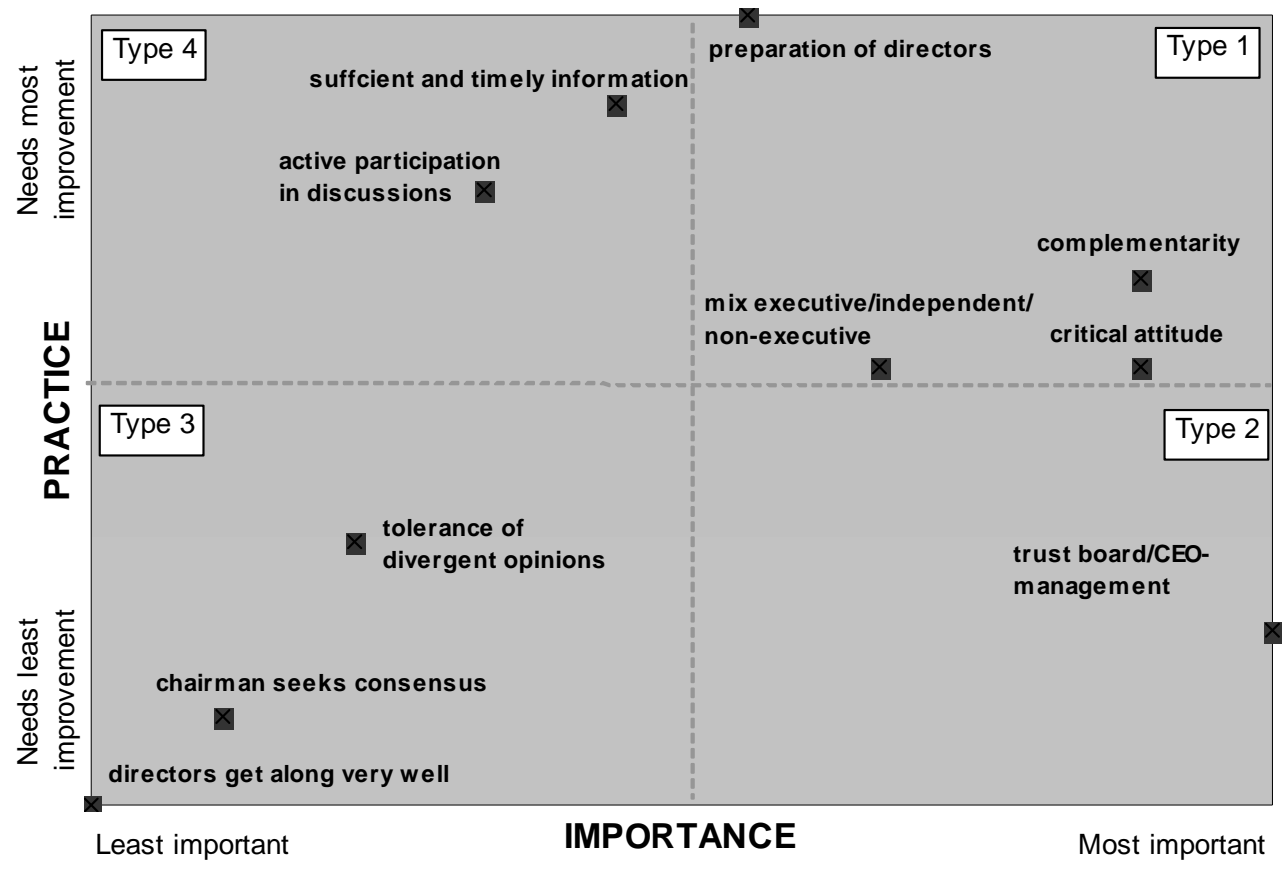

${ }^{9}$ For the sake of presenting the results more clearly in the picture, we have reversed the values of the importance and corrigible scores 